\title{
Evaluation of tomato rootstocks and its use to control bacterial wilt disease
}

\section{Avaliação de porta-enxertos de tomateiro e o uso da enxertia no controle da murcha bacteriana}

\author{
Suane Coutinho Cardoso ${ }^{1 *}$; Ana Cristina Fermino Soares²; \\ Alexsandro dos Santos Brito ${ }^{1}$; Andiale Pinto dos Santos ${ }^{3}$; \\ Francisco Ferraz Laranjeira ${ }^{4}$; Lea Araújo de Carvalho ${ }^{5}$
}

\begin{abstract}
Tomato plants are susceptible to bacterial wilting, which causes production losses varying from 10 to $100 \%$. A method for controlling this disease is the use of grafting on resistant rootstocks. This work had the objective of evaluating tomato genotypes for the resistance to Ralstonia solanacearum and the grafting technique as an alternative for the bacterial wilt control in the region of Recôncavo Baiano, Brazil. To evaluate the resistance to $R$. solanacearum, four local genotypes, collected in different regions of Bahia, the cv. Santa Clara as a susceptible treatment, and the Hawaii 7996 (H7996), as a resistant treatment were studied. For the evaluation of grafting method for control of bacterial wilt, the H7996 was used as rootstock, and the cvs. Santa Clara, Santa Cruz Kada, and Débora Plus were used as the scion plants. Both experiments were evaluated in an area infested with $R$. solanacearum, for a period of 65 days for the selection of the rootstocks and 45 days for the evaluation of the grafting method. Only the H7996 can be recommended as a $R$. solanacearum resistant rootstock. The other genotypes showed susceptibility to the pathogen. The grafting on the H7996 did not show incompatibility with the scion tomato cultivars tested and reached $100 \%$ control of the bacterial wilt disease, for all treatments, suggesting that this method can be used as an alternative for the bacterial wilt control, allowing the production of susceptible tomato cultivars in areas infested with $R$. solanacearum.
\end{abstract}

Key words: Solanum lycopersicum, Ralstonia solanacearum, H7996

\section{Resumo}

A suscetibilidade do tomateiro à murcha bacteriana (Ralstonia solanacearum) causa perdas que vão de 10 a $100 \%$ na produção e uma das alternativas de controle que vem sendo utilizada é a enxertia com porta-enxerto resistente. Este trabalho teve o objetivo de avaliar genótipos de tomateiro quanto à resistência a $R$. solanacearum e a enxertia como alternativa para o controle da murcha bacteriana do tomateiro na região do Recôncavo Baiano. Para avaliação da resistência a $R$. solanacearum, utilizaramse quatro genótipos de tomateiro silvestres coletados em diferentes regiões da Bahia, a cv. Santa Clara como testemunha suscetível e o Hawaii 7996 (H7996) como testemunha resistente. Para a avaliação da enxertia no controle da murcha bacteriana do tomateiro, utilizou-se como porta-enxerto o H7996 e como

1 Profs. Drs. Instituto Federal de Educação, Ciência e Tecnologia Baiano, Campus Guanambi, Distrito de Ceraíma, s/n, Guanambi, BA, 46430-000. E-mail: suanecardoso@gmail.com; alexsandrobrt@gmail.com

2 Prof ${ }^{\mathrm{a}}$. Dr ${ }^{\mathrm{a}}$ Universidade Federal do Recôncavo da Bahia, UFRB, Centro de Ciências Agrárias, Ambientais e Biológicas, CCAAB, Cruz das Almas, BA. E-mail: acsoares@ufrb.edu.br

3 Doutoranda. Embrapa Meio Ambiente, Rod. SP 340. Km 127, Tanquinho, Jaguariúna, SP. E-mail: andialepsantos@bol.com.br

4 Pesquisador Dr. Embrapa Mandioca e Fruticultura, Rua Embrapa, s/n, Cruz das Almas, BA. E-mail: chico@embrapa.cnpmf.br

5 Prof ${ }^{\mathrm{a}}$. Dr ${ }^{\mathrm{a}}$ UFRB, Centro de Ciências Agrárias, Ambientais e Biológicas, Cruz das Almas, BA. E-mail: learaujo@ufrb.edu.br

Author for correspondence 
enxerto as cultivares Santa Clara, Santa Cruz Kada e Débora Plus. Os dois experimentos foram avaliados em infectário de $R$. solanacearum, por um período de 65 dias, para a seleção de porta-enxertos e 45 dias para a avaliação da enxertia, observando-se o sintoma de murcha bacteriana. Apenas o H7996 pode ser recomendado como porta-enxerto resistente a $R$. solanacearum. Os demais genótipos apresentaram suscetibilidade ao patógeno. A enxertia com esse híbrido não apresentou incompatibilidade com as cultivares avaliadas e promoveu $100 \%$ de controle da murcha bacteriana, em todos os tratamentos, sugerindo que essa técnica pode ser utilizada como método alternativo de controle da murcha bacteriana, permitindo a produção de cultivares comerciais de tomateiro, suscetíveis à doença, em áreas infestadas com $R$. solanacearum.

Palavras-chave: Solanum lycopersicum, Ralstonia solanacearum, H7996

\section{Introduction}

Tomato (Solanum lycopersicum) is one of the most cultivated crops in Brazil, and is produced in all States. However, it is frequently affected by several diseases, the bacterial diseases being responsible for large yield losses (PEIXOTO, 1997). Among these, the bacterial wilt caused by Ralstonia solanacearum (Smith) Yabuuchi et al. is the most important, being able to cause crop losses from 10 to $100 \%$ (LOPES, 1994), under environmental conditions of high temperature and high soil humidity (HAYWARD, 1991; LOPES; SANTOS, 1994).

The Ralstonia solanacearum has a worldwide distribution, high genetic variability and - with a wide host range within more than 33 botanical families (HAYWARD, 1994; TAKATSU; LOPES, 1997; KUROZAWA; PAVAN, 2005). It is native of the majority of Brazilian soils, widely found in solanaceous and musaceous species (KUROZAWA; PAVAN, 2005).

Control of bacterial wilt is very difficult, due to the wide distribution of host plants, high genetic variability and its survival in soil for long periods (TAKATSU et al., 1984; REIFSCHNEIDER; TAKATSU, 1985; HAYWARD, 1994). The major control methods are preventive measures or cultural methods which aim at avoiding or delaying of pathogen spread in production areas (SILVEIRA; MARIANO; MICHEREFF, 1996).

As an alternative to the control of soilborne pathogens, grafting techniques in solanaceous vegetables such as tomato, eggplant and green pepper, and cucurbitaceous such as cucumber, watermelon, and melon, have been widely used with success (KAWAIDE, 1985; GÓMEZ, 1997; RIZZO et al., 2004). This method, which involves the use of a commercial, but susceptible cultivars on a resistant rootstock belonging to other cultivar, plant species or genera of the same family, has the objective of avoiding the contact of the susceptible plant with the pathogen, keeping the root system healthy, and allowing the normal plant functions of soil water and nutrient absorption (PEIL, 2003).

In members of the Solanaceae, especially the tomato crop, grafting techniques have been used in order to control diseases caused by Fusarium. oxysporum f. sp. lycopersici, Verticillium dahliae, R. solanacearum, Pyrenochaeta lycopersici, F. oxysporum f. sp. radicis - lycopersici, nematodes, and the virus ToMV (LEE, 1994; ODA, 1995; GÓMEZ, 1997).

Wild tomato plants with resistance to bacterial wilt have been used as rootstocks for Chinese tomato cultivars. The rootstocks 'CH-2-26', 'CH-2-25', and ' $\mathrm{CH}-2-21$ ' promoted the control of $100 \%, 86,7$ $\%$, and $80 \%$ respectively, delaying symptoms until the $25^{\text {th }}$ and $40^{\text {th }}$ day after planting, compared to the susceptible plants (LU et al., 1992). The H7996 has been recommended as a rootstocks tomato because it has a high level of resistance to bacterial wilt (WANG et al., 1998; BLACK et al., 2003).

In differents regions of Brazil, where tomato cultivars usually succumbs upon infection, such as $R$. solanacearum, and suitable environmental 
conditions, grafting on species of the genera Solanum, such as 'Anchor T' and 'BGH 3472' (S. lycopersicum) jurubeba (S. jurubeba), and juna $(S$. toxicarium) has been used with success (TOKESHI; CARVALHO, 1980; PEIL, 2003; LOOS; CALIMANI; SILVA, 2009; GOTO et al., 2010).

In the Recôncavo region of the State of Bahia, Brazil, wilting caused by $R$. solanacearum biovar III has threatened solanaceous crops such as tomato plants, eggplants, and green pepper plants. Also, there are no studies concerning the viability of the grafting method with resistant rootstocks for control of bacterial wilt in this region of Brazil.

This work had the objective of evaluating native tomato genotypes (round cherry from the city of Cruz das Almas - RCA and pear shaped from the city of Cruz das Almas - PCA,) and regional tomato genotypes (round cherry from the city of Barreiras - RBA and pear shaped 'Lampadinha' from the city of Amargosa - PLA), as to their resistance to $R$. solanacearum biovar III, and the grafting method for the control of tomato bacterial wilting.

\section{Materials and Methods}

This work was carried out in the city of Cruz das Almas, State of Bahia, Brazil, in an experimental area of Federal University of Bahia Recôncavo. The average temperature of $24.77{ }^{\circ} \mathrm{C}$, relative air humidity $78.40 \%$, under sprinkle irrigation conditions.

\section{Evaluation of rootstocks with resistance to bacterial wilt}

The genotypes evaluated were: the cultivar Santa Clara (SC), as a suscetible control, the Hawaii 7996 (H7996) from the Asian Vegetable Research and Development Center - AVRDC in Taiwan (BLACK et al., 2003), as a resistant control, and four native and regional genotypes: round cherry from the city of Barreiras (RBA), round cherry from the city of Cruz das Almas (RCA), pear shaped from the city of Cruz das Almas (PCA), and pear shaped 'Lampadinha' from the city of Amargosa, State of Bahia (PLA). The SC and H7996 are classified as $S$. lycopersicum the native RBA and RCA as $S$. lycopersicum var. cerasiforme, and the native PCA and PLA as $S$. pimpinellifolium, according to the taxonomy described by Rick, Laterrot, Philouze (1990) and Pavan, van Heusden, Bai (2009).

For seedling production, seeds from the different genotypes were sown in plastic disposable cups (3 seeds/cup) with $200 \mathrm{ml}$ of plant growing potting mix Plantmax ${ }^{\circledR}$. Eight days after seed germination, only one plantlet was left per cup. The tomato seedlings were grown under nursery conditions, being irrigated daily with tap water.

Thirty-five days after sowing, the seedlings were transplanted to small plots $(1.5 \mathrm{~m} \times 8.5 \mathrm{~m})$ with soil infested with $R$. solanacearum, biovar III. Plant spacing was $20 \mathrm{~cm}$ between plants and 90 $\mathrm{cm}$ between lines. The experimental design was in randomized blocks with six treatments, and each plot formed by five plants, with a total of thirty plants per treatment. Symptoms of bacterial wilting were monitored at every other day for a period of 65 days.

The disease index was calculated for each genotype, days for symptoms to appear divided by the period of disease evaluation (65 days). Disease indices were transformed in $\operatorname{arcsen} \sqrt{x}$, and submitted to the analysis of variance and ScottKnott test $(\mathrm{P}<0.01)$. Based on the pathosystem features and the kind of pathogen inoculation, the monomolecular model was chosen to fit the disease progress curves. The monomolecular model $\mathrm{y}(\mathrm{t})=$ 1 - [(1-yi) exp (-r.t)] was adjusted to the disease progress curve (proportion of wilting plants $x$ days after transplanting) by means of a non-linear regression analysis with Statistica 5.0 software. Regression was performed by Quasi-Newton method, which estimates assymptotically the 
second order derivatives (partials) from the function of loss (loss $=$ (observed - predicted $) 2$ ) and uses them to determine the parameters movement from iteration to interaction. The decision if the model was adequate to describe our data was decided based on the coefficient of determination between the observed values and the predicted values and the occurrence or not of patterns in the graphs of residuals versus predicted values (1). The equations with reasonable coefficient of determination ( $>$ 0.900 ) were accepted as appropriate only when their residual did not show detectable patterns. The disease progress rates $(r)$ for the monomolecular model were considered only for the equations which presented a good fit.

\section{Evaluation of the grafting method with a resistant rootstock for the control of tomato bacterial wilt}

The H7996, resistant to bacterial wilt, was used as rootstock, and three commercially available cultivars susceptible to $R$. solanacearum, cv. Santa Clara, cv. Santa Cruz Kada and the hybrid Débora Plus, were used as the scion plants.

For seedling production, a growing medium composed of a mixture of the plant growth potting mix Plantmax ${ }^{\circledR}$ and sand, in the proportion of 2:1 (v:v) was used. The rootstock seedlings (H7996) was grown in black plastic bags with $500 \mathrm{~mL}$ of the plant growth medium and the scion seedlings were grown in disposable plastic cups with $300 \mathrm{~mL}$ of the plant growth medium. The scion plants were sown eight to ten days after the rootstock sowing, as recommended by Yoshioka, Takahashi and Arai (1985). The seedlings used as control plants, without grafting were sown in the same day as the rootstocks, also in black plastic bags with $500 \mathrm{ml}$ of the plant growth medium.

Grafting was performed when the rootstocks presented five to six unfolded true leaves (30 days after sown), and the scions with three to four true unfolded leaves (20 days after sowing), as described by Yamakawa (1982). Cleft grafting was used, in which the rootstock plant is decapitated above the second true leaf, and a wedge shaped cut is made in the stem with a depth of $1.5 \mathrm{~cm}$. A wedge shaped terminal scion plant with three to four true leaves, cut at the hypocotyls level, was inserted in the cleft at the cut end of the rootstock. The cuts were done with a surgical blade, disinfested with a solution of $70 \%$ alcohol after each cut. The scion and rootstock were held together with Parafilm $\mathrm{M}^{\circledR}$ (American National Can, Neenah, WI), which allowed a adequate holding and protection of the grafted area, due to its elasticity. Also, it spontaneously braking after graft healing, what eased its removal and avoided injuries to the grafted plant.

After grafting, the plants were kept in an acclimatizing chamber with high humidity and $50 \%$ luminosity. This chamber had the following characteristics: two wood tables with $1.0 \mathrm{~m}$ width, $3.0 \mathrm{~m}$ length, $0.80 \mathrm{~m}$ height, and $0.50 \mathrm{~m}$ spacing between them, covered with a transparent plastic, hold by PVC $1 / 2$ " tubes in a round shape with a height of $1.20 \mathrm{~m}$. The tables were covered with plastic and newspaper, with disposable cups full of tap water spread all over the tables, in order to maintain the air humidity around $90 \%$. The plants were maintained in this chamber for of ten days, and periodically the lateral parts of the plastic were raised in order to ventilate the chamber, and the plants were irrigated with sprinklers to maintain high air humidity.

Five days after grafting, each plant received 50 $\mathrm{ml}$ of Hoagland nutrient solution, and ten days after grafting, the plastic cover was removed and the plants were left under 50\% shading conditions, for acclimatizing.

Four days after acclimatizing with 50\% shading, the plants were transplanted to the $R$. solanacearum biovar III infested area. This area consisted of small plots separated by a cement wall $(1.5 \mathrm{~m} \times 8 \mathrm{~m})$, which contained soil previously infested with the pathogen, by planting tomato seedlings inoculated with $R$. solanacearum, biovar III for three consecutive plantings and soil incorporation of the 
wilting tomato plants. Planting of healthy tomato seedlings cv. Santa Clara, after incorporation of the wilting tomato plants, and observation of 100 $\%$ incidence of bacterial wilting confirmed the homogeneity of the infested area.

Before seedling transplant, each plot received $1500 \mathrm{~g}$ of simple superphosphate, $333 \mathrm{~g}$ of potassium chloride, and $111 \mathrm{~g}$ of urea. The plant spacing was $0.90 \mathrm{~m}$ between lines and $0.30 \mathrm{~m}$ between plants. The bacterial wilting symptoms were recorded at every other day, for a period of 45 days.

The experimental design was in randomized blocks, with 7 treatments, 4 replications, and 5 plants per plot. The treatments were the following: the combinations H7996-'Santa Clara', H7996'Santa Cruz Kada', H7996-'Débora Plus', and the ungrafted plants, including H7996 plants.

\section{Results and Discussion}

\section{Evaluation of rootstocks resistant to bacterial wilt}

Among the evaluated materials, the H7996 did not present symptoms of bacterial wilt throught the entire crop cycle, confirming its resistance to $R$. solanacearum biovar III (Figure 1, Table 1).

The cultivar 'Santa Clara', the native genotypes PLA and RCA presented the lowest disease indexes, which corresponded to the highest disease progress rates observed (Table 1), being grouped as the most susceptible genotypes to bacterial wilt. The native genotypes PCA and RBA exhibited higher indexes, which corresponded to lower disease progress rates, being grouped as the less susceptible ones (Table 1). The cultivar Santa Clara presented 40 $\%$ of wilted plants at 15 days after transplanting, reaching $93 \%$ wilting incidence at 30 days after transplanting, confirming its high susceptibility to R. solanacearum (Figure 1).

Figure 1. Incidence of bacterial wilt (\%) for the cultivars 'Santa Clara' (SC), hybrid 'Hawaii 7996' (HW), round cherry from the city of Barreiras (RBA), pear shaped from the city of Amargosa (PLA), round cherry from the city of Cruz das Almas (RCA), and pear shaped from the city of Cruz das Almas (PCA).

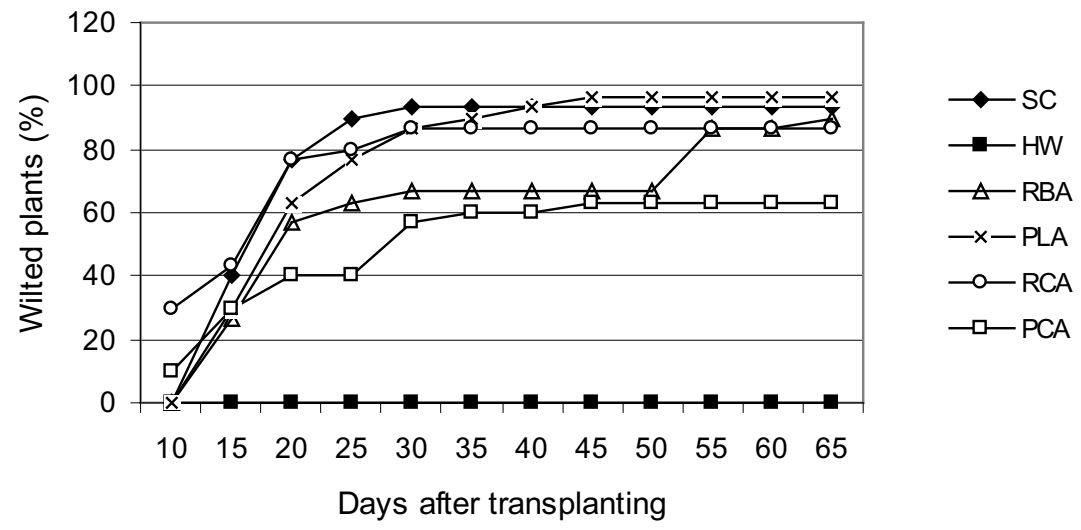

Source: Elaboration of the authors. 
Table 1. Intensity of bacterial wilting of different tomato genotypes, evaluated in experimental plots infested with $R$. solanacearum biovar III, in the city of Cruz das Almas, State of Bahia, Brazil.

\begin{tabular}{lccc}
\hline Treatments & Index $^{\mathbf{1}} \mathbf{( \% )}$ & $\mathbf{D P R}^{\mathbf{2}}$ & $\mathbf{R}^{\mathbf{2}}$ \\
\hline Hawaii 7996 (HW) & $1.00 \mathrm{a}$ & 0 & - \\
Pear shaped Cruz das Almas (PCA) & $0.535 \mathrm{~b}$ & 0.028 & 0.942 \\
Cherry Round Barreiras (RBA) & $0.474 \mathrm{~b}$ & 0.066 & 0.965 \\
Pear shaped 'Lampadinha' Amargosa (PLA) & $0.346 \mathrm{c}$ & 0.095 & 0.993 \\
Cherry round Cruz das Almas (RCA) & $0.338 \mathrm{c}$ & 0.086 & 0.940 \\
cv. Santa Clara (SC) & $0.322 \mathrm{c}$ & 0.133 & 0.986 \\
\hline CV \% & 13.15 & - & -
\end{tabular}

${ }^{1}$ Disease index. Original data presented. For statistical analysis, data was transformed in $\operatorname{arcsen} \sqrt{ } \mathrm{x}$.

${ }^{2}$ Disease progress rate.

Means followed by the same letter in the column, do not differ statistically, by the grouping test Scott-Knott at $1 \%$ probability.

Source: Elaboration of the authors.

The native genotypes RCA and PLA exhibited 87 $\%$ wilt incidence at 30 days after transplanting. RCA maintained that index until the end of the evaluation period, but PLA increased the wilt index to $97 \%$. The genotype PCA had early disease onset, with 10 $\%$ of wilted plants at 10 days after transplanting. However, it reached a wilting incidence of $57 \%$ and $63 \%$ at 30 and 45 days after transplanting, respectively, with disease progress rate $4.75,3.39$ and 3.07 times lower than that observed for $\mathrm{cv}$. Santa Clara, PLA and RCA, respectively, which were grouped as the most susceptible genotypes.

Although variation in the reaction of the tomato genotypes to bacterial wilt was detected, only the H7996 can be recommended as a rootstock resistant to $R$. solanacearum.

According to Morgado, Lopes, Takatsu (1992), Quezado-Soares e Lopes (1994), Martins et al. (1998), and Sirtoli et al. (2008), there are several studies about the evaluation of tomato and eggplant genotypes for resistance to bacterial wilt, for plant breeding programs. With regard to these native tomato genotypes, their susceptibility to $R$. solanaceraum and the viability of using them as resistant rootstocks was not found in the reviewed literature.
Evaluation of grafting with a resistant rootstock for control of tomato bacterial wilt

A $93.4 \%$ grafting success was obtained for all the combinations ('Santa Clara', 'Santa Cruz Kada' e 'Débora Plus' grafted on H7996). At the transplanting phase, only two plants (out of 60 grafted plants) died due to a grafting point rupture, which suggests the necessity of support the plants in the moment of transplanting.

The grafting on H7996 promoted $100 \%$ control of bacterial wilting for all treatments, which demonstrates the viability of grafting as a method for bacterial wilt control (Figure 2). The grafted plants reached fruit production stage (data not shown), while the seedlings of 'Santa Clara', 'Santa Cruz Kada' and 'Débora Plus', presented $100 \%$ incidence of bacterial wilt inserir (Figure 2). Among the susceptible control treatments, cultivar Santa Clara was the first to show wilting symptoms at 11 days after transplanting, followed by 'Débora Plus' which showed symptoms at 14 days, and 'Santa Cruz Kada', which showed symptoms at 17 days (Figure 2). 
Figure 2. Incidence of bacterial wilt (\%) for seedlings Hawaii 7996 (HW), cv. Santa Clara (SC), cv. Santa Cruz Kada (SCK), cv. Débora Plus (DP) and the grafting combinations HW-SC, HW-SCK e HW-DP, planted in an area infested with $R$. solanacearum, in the city of Cruz das Almas, State of Bahia. It should be noted that the curves for HW and the grafted plants are on the $\mathrm{X}$-axis, since the disease progress rate is zero.

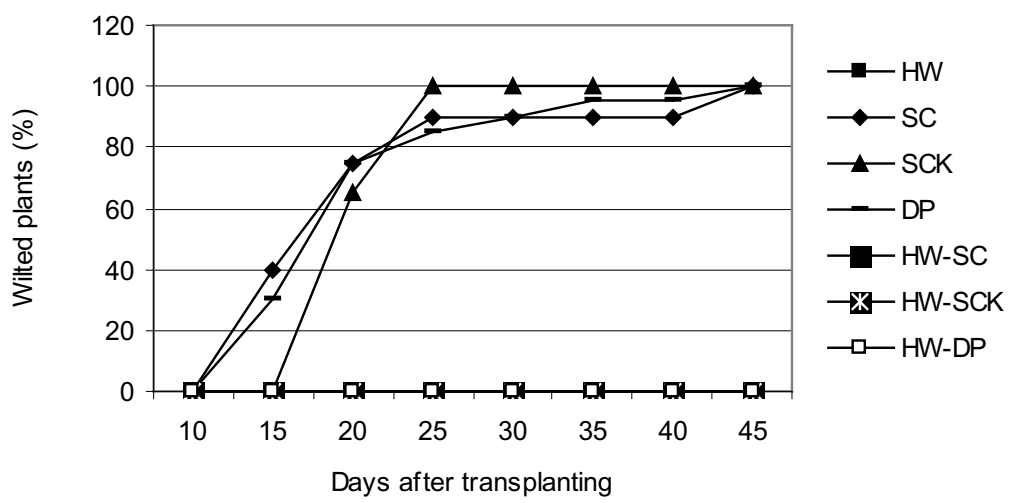

Source: Elaboration of the authors.

In the experimental area, the occurrence of leaf spots caused by Stemphylium solani and Alternaria solani, stem rot (Sclerotium rolfsii) and crown galls caused by Meloidogyne incognita were observed. The H7996 was also susceptible to Sclerotium rolfsii and Meloidogyne incognita, but did not show leaf spots.

Grafting has been used as a method to promote protection of Solanaceae and Cucurbitaceae to soilborne diseases, allowing growing these crops in infested areas. Althought it has been used in countries such as Japan, Holand and Spain, in Brazil is a new method for the production of horticulture seedlings (PEIL, 2003). Farmers from the State of São Paulo which grow japanese green peppers use grafting technique in order to reduce losses due to soilborne phytopathogenic fungi and plant parasitic nematodes (CANIZARES; GOTO, 2002). Others studies with grafting in tomato have been carried out to evaluate the yield and fruit quality of tomato (CARDOSO et al., 2006a; CARDOSO et al., 2006b; LOOS; CALIMANI; SILVA, 2009).

The present work demonstrated the viability of using the grafting technique with the H7996 as a method for the control of bacterial wilt, therefore, allowing the growth and yield of susceptible tomato cultivars in areas infested with $R$. solanacearum.

However, it should be pointed out that, due to genetic variability of soilborne plant pathogens, research programs should always be looking for resistant rootstocks or commercial cultivars, due to problems caused by the occurrence of different pathogen species, or races, strains, and biovars within a given species (LOPES; QUEZADOSOARES; MELO, 1994; KOBORI, 1999). These considerations are valid for the pathosystem $R$. solanacearum - Solanaceae, for which there is a high genetic variability of the pathogen, which makes it difficult to develop effective control strategies (UESUGI; TOMITA, 2002). It should also be considered that the search for resistant native germplasm is a promising field, considering that to have resistance to soilborne pathogens, without affecting the commercial value of the crop, is important in order to avoid dependence on imported hybrids (PEIL, 2003). 


\section{Acknowledgements}

Our thanks to Dr. Jaw-Fen Wang for kindly sending the seeds of Hawaii 7996, from the Asian Vegetable Research and Development Center (AVRDC), in Taiwan.

\section{References}

BLACK L. L.; WU, D. L.; WANG, J. F.; KALB, T.; ABBASS, D.; CHEN, J. H. Grafting tomatoes for production in the hot-wet season. Taiwan: Asian Vegetable Research and Development Center, 2003. 6 p. (AVRDC International Cooperators' Guides).

CANIZARES, K. A. L.; GOTO, R. Comparação de métodos de enxertia em pepino. Horticultura Brasileira, Brasília, v. 20, n. 1, p. 95-99, 2002.

CARDOSO, S. C.; SOARES, A. C. F.; BRITO, A. dos S.; CARVALHO, L. A.; LEDO, C .A. S. Viabilidade de uso do híbrido Hawaii 7996 como porta-enxerto de cultivares comerciais de tomate. Bragantia, Campinas, v. 65, n. 1, p. 89-96, 2006a.

CARDOSO, S. C.; SOARES, A. C. F.; BRITO, A. S.; CARVAlHO, L. A.; PEIXOTO, C. P.; PEREIRA, M. E. C.; SOUZA, E. G. Qualidade de frutos de tomateiro com e sem enxertia. Bragantia, Campinas, v. 65, n. 2, p. $269-$ 274, $2006 b$.

GÓMEZ, A. M. Injerto de hortalizas. Valência: Generalitat Valenciana. 1997. 88 p. (Divulgación técnica, 40).

GOTO, R.; SIRTORI, L. F.; RODRIGUES, J. D.; LOPES, M. C. Produção de tomateiro, híbrido momotaro, em função do estádio das mudas e da enxertia. Ciência Agrotecnologia, Lavras, v. 34, n. 4, p. 961-966, 2010.

HAYWARD, A. C. Biology and epidemiology of bacterial wilt caused by Pseudomonas solanacearum. Anual Review Phytopathology, Palo Alto, v. 29, n. 1, p. 65-87, 1991.

The hosts of Pseudomonas solanacearum. In: HAYWARD, A. C.; HARTMAN, G. L. (Ed.). Bacterial wilt: the disease and its causative agent, Pseudomonas solanacearum. Wallingford: CAB International, 1994. p. 9-24.

KAWAIDE, T. Utilization of rootstocks in cucurbits production in Japan. Japan Agricultural Research Quarterly, Ibaraki, v. 18, n. 4, p. 284-289, 1985.

KOBORI, R. F. Controle da murcha de Fitóftora (Phytophthora capsici) em pimentão (Capsicum annuum L.) através da enxertia. 1999. Tese. (Doutorado em Proteção de Plantas) - Faculdade de Ciências Agronômicas. Universidade Estadual Paulista Júlio de Mesquita Filho, Botucatu.

KUROZAWA, C.; PAVAN, M. A. Doenças do tomateiro (Lycopersicon esculentum) In: KIMATI, H. et al. (Ed.). Manual de fitopatologia. São Paulo: Ceres, 2005. v. 2, cap. 67, p. 607-626.

LEE, J. M. Cultivation of grafted vegetables. I. Current status, grafting methods and benefits. Hortscience, Alexandria, v. 29, n. 4, p. 235-239, 1994.

LOOS, R. A.; CALIMANI, F. R. B.; SILVA, D. J. H. Enxertia, produção e qualidade de tomateiros cultivados em ambiente protegido. Ciência Rural, Santa Maria, v. 39, n. 1, p. 232-235, 2009.

LOPES, C. A. Ecologia de Pseudomonas solanacearum. In: TALLER SOBRE ENFERMIDADES BACTERIANAS DE LA LAPA, 1., 1994, Brasília. Memórias... Brasília: Centro Nacional de Pesquisa de EMBRAPA/Hortaliças, 1994. p. 17-22.

LOPES, C. A.; QUEZADO-SOARES, A. M.; MELO, P. E. Differential resistance of tomato cultigens to biovars I and III of Pseudomonas solanacearum. Plant Disease, Saint Paul, v. 78, n. 11, p. 1097-1094, 1994.

LOPES, C. A.; SANTOS, J. R. M. dos. Doenças do tomateiro. Brasília: Embrapa-SPI/Embrapa-CNPH, 1994. $61 \mathrm{p}$.

LU, M. A; CHEN, Y. H.; LIN, M. S.; CHEN, H. P. An experiment using grafting for control of tomato bacterial wilt. Plant Protection, Tokyo, v. 18, n. 3, p. 3-25, 1992.

MARTINS, M. O. Fontes de resistência em tomateiro a Pseudomonas solanacearum. Horticultura Brasileira, Brasília, v. 6, n. 2, p. 17-19, 1998.

MORGADO, S. H.; LOPES, C. A.; TAKATSU, A. Avaliação de genótipos de berinjela para resistência à murcha bacteriana. Horticultura Brasileira, Brasília, v. 10, n. 2, p. 77-79, 1992.

ODA, M. New grafting methods for fruit bearing vegetables in Japan. Japan Agricultural Research Quarterly, Ibaraki, v. 29, n. 3, p. 187-194, 1995.

PAVAN, S.; van HEUSDEN, A. W.; BAI, Y. Solanum lycopersicum (tomato). eLS: John Wiley \& Sons, Ltd. 2009.

PEIL, R. M. Grafting of vegetable crops. Ciência Rural, Santa Maria, v. 33, n. 6, p. 1169-1177, 2003.

PEIXOTO, A. R. Biological control of bacterial wilt of tomato by fluorescent Pseudomonas spp. Ciência Rural, Santa Maria, v. 27, n. 1, p. 153-160, 1997. 
QUEZADO-SOARES, A. M.; LOPES, C. A. Resistência de genótipos de tomateiro a biovares I e III de Pseudomonas solanacearum. Horticultura Brasileira, Brasília, v. 12, n. 2, p. 161-165, 1994.

REIFSCHNEIDER, F. J. B.; TAKATSU, A. Pseudomonas solanacearum no Brasil: aspectos macroepidemiológicos. Fitopatologia Brasileira, Brasília, v. 10, n. 2, p. 123, 1985.

RICK, C. M.; LATERROT, H.; PHILOUZE, J. A revised key for the Lycopersicon species. TGC. Report, Flórida, v. 40, p. 31, 1990.

RIZZO, A. A. N.; CHAVES, F. C. M.; LAURA, V. A.; GOTO, R. Evaluation of grafting types and rootstocks for muskmelon. Horticultura Brasileira, Brasília, v. 22, n. 4, p. 808-810, 2004.

SILVEIRA, N. S. S.; MARIANO, R. L. R.; MICHEREFF, S. J. Pseudomonas solanacearum no Brasil. Summa Phytopathologica, Jaboticabal, v. 22, n. 2, p. 97-111, 1996.

SIRTOLI, L. F.; CERQUEIRA, R. C.; FERNANDES, L. M. S.; RODRIGUES, J. D.; GOTO, R.; AMARAL, J. L. Avaliação de diferentes porta-enxertos de tomateiro cultivados em ambiente protegido. Biodiversidade, Rondonópolis, v. 7, n. 1, p. 28-28, 2008.

TAKATSU, A.; LOPES, C. A. Murcha bacteriana em hortaliças: avanços científicos e perspectivas de controle. Horticultura Brasileira, Brasília, v. 15, n. 1, p. 170-177, 1997. Suplemento.
TAKATSU, A.; SILVA, C. B.; REIFSCHNEIDER, F. J. B. Variabilidade e distribuição de Pseudomonas solanacearum de solanáceas nas diferentes regiões do Brasil. Fitopatologia Brasileira, Brasília, v. 9, n. 2, p. 387-387, 1984.

TOKESHI, H.; CARVAlHO, P. C. T. Doenças do tomateiro Lycopersicon esculentum Mill. In: GALLI, F. (Ed.). Manual de fitopatologia. 2. ed. São Paulo: Ceres, 1980. v. 2, p. 551-552.

UESUGI, C. H.; TOMITA, C. K. Murcha bacteriana. Revista Cultivar HF, Pelotas, n. 11, p. 12-14, 2002.

WANG, J.-F.; THOQUET, P., OLIVIER, J.; GRIMSLEY, N. Genetic analysis of quantitative resistance loci (QRL) of tomato variety Hawaii 7996 in Taiwan. In: PRIOR, P.; ALLEN, C.; ELPHINSTONE, J. (Ed.). Bacterial wilt disease. Molecular and ecological aspects. Berlin: Springer,Verlag, 1998, p. 246-249.

YAMAKAWA, K. Use of rootstocks in Solanaceous fruit-vegetable production in Japan. Japan Agricultural Research Quarterly, Ibaraki, v. 15, n. 3, p. 175-180, 1982.

YOSHIOKA, H.; TAKAHASHI, K.; ARAI, K. Studies on the translocation and accumulation of photosynthates in fruit vegetables. VII. Excess accumulation of carbohydrates in young grafted tomato plants. Bulletim Vegetable and Ornamental Crops Research Station Series A, Tsushi, v. 13, n. 1 p. 1-10, 1985. 
